\title{
KEPEMILIKAN HAK ATAS TANAH BAGI ORANG ASING DI INDONESIA
}

\author{
Mira Novana Ardani \\ Fakultas Hukum Universitas Diponegoro \\ miranovana@yahoo.com
}

\begin{abstract}
ABSTRAK
Orang asing yang berkedudukan di Indonesia memerlukan tanah yang akan dijadikan tempat tinggal mereka selama berada di Indonesia. Penelitian ini menggunakan pendekatan yuridis empiris/sosiologis. Pengaturan kepemilikan hak atas tanah bagi orang asing di Indonesia, mulai dari mendapat izin tinggal berada di Indonesia sampai dengan memperoleh hak atas tanah untuk tempat tinggalnya perlu mendapat perhatian. Pelaksanaan dari aturan yang telah ada harus dilaksanakan secara konsisten.
\end{abstract}

\section{Kata kunci: Hak Atas Tanah; Kepemilikan; Orang Asing}

\section{A. PENDAHULUAN}

\section{Latar Belakang}

Seluruh wilayah Indonesia adalah kesatuan tanah air dari seluruh rakyat Indonesia, yang bersatu sebagai bangsa Indonesia. Selama rakyat Indonesia yang bersatu sebagai bangsa Indonesia masih ada dan selama bumi, air dan ruang angkasa Indonesia itu masih ada pula dalam keadaan yang bagaimanapun tidak ada sesuatu kekuasaan yang akan dapat memutuskan atau meniadakan hubungan tersebut. ${ }^{1}$

Wilayah Indonesia sangat luas, karena Indonesia terdiri dari berbagai pulau-pulau serta wilayahnya berada dari Sabang sampai Merauke. Oleh karena itu Pemerintah memiliki tugas untuk

${ }^{1}$ A.P.Parlindungan, 1990, Komentar Atas Undang-Undang Pokok Agraria, Bandung: Alumni, halaman 25 dapat mempertahankan, menjaga, serta mengelolanya supaya dapat memberikan manfaat terutama kepada rakyat Indonesia itu sendiri. Hal ini terdapat dalam Pasal 33 ayat 3 Undang-Undang Dasar 1945 yang menyatakan bahwa bumi, air dan kekayaan alam yang terkandung di dalamnya dikuasai oleh negara, dan dipergunakan untuk sebesar-besar kemakmuran rakyat.

Penduduk yang menempati wilayah Indonesia tidak hanya Warga Negara Indonesia, akan tetapi juga orang asing yang bertempat tinggal di Indonesia. Dalam perkembangannya, orang asing yang berada di Indonesia makin lama semakin banyak jumlahnya. Salah satu sebabnya dikarenakan adanya kemajuan ilmu pengetahuan dan teknologi, serta keterbukaan antar negara 
dalam hubungan internasional. Misalnya untuk orang asing yang bekerja di Indonesia, baik itu melalui saham yang mereka tanamkan pada sebuah perusahaan di Indonesia, maupun perusahaan mereka yang berada di Indonesia. Walaupun untuk perusahaan berbadan hukum asing tidak banyak memiliki kesempatan untuk berbisnis di Indonesia. Namun, ada bidang-bidang tertentu yang terbuka untuk dimasuki perusahaan asing melakukan kegiatan bisnis. Bidang-bidang tersebut antara lain bidang pertambangan minyak dan gas bumi, bidang angkatan laut dan angkatan udara khususnya untuk angkutan luar negeri. Selain itu juga di bidang perbankan, perusahaan asing hanya dapat mendirikan kantor cabangnya di Indonesia. ${ }^{2}$

Orang asing tersebut, selama tinggal di Indonesia tentunya memerlukan tempat tinggal untuk bertahan hidup selama berada di Indonesia. Tempat tinggal dapat melindungi dari panasnya sinar matahari, dapat melindungi dari hujan, serta bahaya-bahaya lain yang ada. Tentunya tempat tinggal tersebut memerlukan tanah sebagai tempat berdirinya bangunan yang akan didirikan tersebut.

Negara dalam hal ini Pemerintah harus memiliki pengaturan mengenai kepemilikan hak atas tanah khususnya untuk orang asing yang berkedudukan di Indonesia supaya amanat yang terdapat dalam Pasal 33 ayat 3 Undang-Undang

2 Gatot Supramono, 2012, Hukum Orang Asing di Indonesia, Banjarmasin, Sinar Grafika, halaman 3
Dasar 1945 tetap dapat terlaksana dengan baik. Bahwa bumi, air, dan kekayaan alam yang terkandung didalamya dipergunakan untuk mewujudkan kemakmuran seluruh rakyat Indonesia. Berdasarkan latar belakang tersebut di atas, maka akan dilihat bagaimana pengaturan kepemilikan hak atas tanah bagi orang asing di Indonesia.

\section{Metode Penelitian}

Metode penelitian yang digunakan menggunakan metode pendekatan yuridis empiris/sosiologis terhadap hukum. Pendekatan yuridis empiris/sosiologis ini adalah untuk memperdalam dan memperluas obyek yang diteliti, karena dalam penelitian ini akan dilihat bagaimana bekerjanya hukum dalam masyarakat dan bagaimana hukum berinteraksi dengan masyarakat, hukum tidak hanya dilihat sebagai suatu entitas normatif yang mandiri atau isoterik, melainkan justru harus dilihat sebagai bagian riil dari sistim sosial yang berkaitan dengan variable social yang lain, ${ }^{3}$ sehingga kepemilikan hak atas tanah bagi Warga Negara Asing di Indonesia dalam implementasinya di samping perlu diteliti dari aspek hukumnya juga realitas empiriknya dalam masyarakat.

Spesifikasi penelitian ini adalah penelitian deskriptif analitis, yaitu berupaya

\footnotetext{
3 Soerjono Soekanto, Pendekatan Sosiologi Terhadap Hukum, Bina Aksara, Jakarta, 1988, hal.9
} 
menggambarkan secara rinci bagaimana implementasi dari peraturan-peraturan yang berhubungan dengan kebijakan mengenai kepemilikan hak atas tanah bagi Warga Negara Asing di Indonesia, tanpa melakukan hipotesa dan perhitungan secara statistik.

Jenis data yang dipergunakan dalam penelitian ini menggunakan data sekunder, yaitu data yang mendukung data primer yang diperoleh melalui studi kepustakaan, studi dokumenter maupun aturan-aturan hukum dalam peraturan perundang-undangan yang berfungsi untuk menunjang kelengkapan data primer. ${ }^{4}$ Selain itu, digunakan juga data primer, yaitu data yang diperoleh di lapangan sebagai data utama. ${ }^{5}$

Sedangkan metode pengambilan data menggunakan bahan hukum primer, merupakan bahan hukum yang mengikat, yaitu peraturan perundang-undangan, terutama yang berhubungan dengan kepemilikan hak atas tanah bagi Warga Negara Asing di Indonesia, bahan hukum sekunder yang memberikan penjelasan mengenai bahan hukum primer antara lain pendapat para sarjana, majalah-majalah berita tanah buku-buku karya ilmiah para sarjana, dan hasil-hasil penelitian yang membahas mengenai hal-hal yang berhubungan dengan pokok bahasan penelitian ini, serta bahan hukum tertier yang mendukung dan memberikan

\footnotetext{
4 lbid

5 Ronny Hanitijo Soemitro, Metodologi Penelitian Dan J urimetri, Ghalia, Jakarta, 1992, hal.52
}

penjelasan bahan hukum primer dan sekunder, seperti kamus bahasa Indonesia, ejaan yang disempurnakan, dan kamus bahasa Inggris.

Setelah data penelitian lapangan dan penelitian kepustakaan terkumpul, kemudian dilakukan suatu analisa yang dihubungkan dengan masalah-masalah yang ada untuk kemudian ditarik kesimpulan yang dapat dipertanggung jawabkan secara obyektip, sehingga diketahui bagaimana kepemilikan hak atas tanah bagi Warga Negara Asing di Indonesia telah sesuai dengan ketentuan peraturan per Undang-Undangan yang berlaku.

\section{Kerangka Teori}

\section{a. Hak Atas Tanah Dalam Hukum Tanah Nasional}

Sesuai dengan isi yang terdapat dalam Pasal 33 ayat (3) Undang-Undang Dasar 1945, bahwa ruang lingkup bumi menurut Undang-Undang Pokok Agraria adalah permukaan bumi, dan tubuh bumi di bawahnya serta yang berada di bawah air. Permukaan bumi sebagai bagian dari bumi juga disebut tanah. Tanah yang dimaksudkan di sini bukan mengatur tanah dalam segala aspeknya, melainkan hanya mengatur salah satu aspeknya, yaitu tanah dalam pengertian yuridis yang disebut hak penguasaan atas tanah. ${ }^{6}$

Hak penguasaan atas tanah berisi wewenang, kewajiban, dan/atau larangan bagi

\footnotetext{
6 Urip Santoso, Hukum Agraria Kajian Komprehensif, Kencana, Jakarta, 2012, halaman 75
} 
pemegang haknya untuk berbuat sesuatu mengenai tanah yang dihaki. Sesuatu yang boleh, wajib, atau dilarang untuk diperbuat, yang merupakan isi hak penguasaan itulah yang menjadi kriterium atau tolok ukur pembeda di antara hakhak penguasaan atas tanah yang diatur dalam Hukum Tanah. ${ }^{7}$

Hak atas tanah termasuk salah satu hak perseorangan atas tanah. Hak perseorangan atas tanah adalah hak yang memberi wewenang kepada pemegang haknya (perseorangan, sekelompok orang secara bersama-sama, badan hukum) untuk memakai, dalam arti menguasai, menggunakan, dan/atau mengambil manfaat dari tanah tertentu.

Hak atas tanah adalah hak yang memberikan wewenang untuk mempergunakan permukaan bumi atau tanah yang bersangkutan demikian pula tubuh bumi dan air serta ruang angkasa yang ada di atasnya, sekedar diperlukan untuk keperluan yang langsung berhubungan dengan penggunaan tanah itu, dalam batas-batas menurut Undang-Undang ini dan peraturan hukum lain yang lebih tinggi. ${ }^{8}$

Negara sebagai organisasi kekuasaan tertinggi seluruh rakyat, mempunyai wewenang berdasar hak menguasai dari Negara sesuai Pasal 2 ayat 2 Undang-Undang Pokok Agraria, yaitu:

7 Boedi Harsono, Hukum Agraria Indonesia, Sejarah Pembentukan Undang-Undang Pokok Agraria Isi Dan Pelaksanaannya, Djambatan, Jakarta, 2008, halaman 24 8 Samun Ismaya, Pengantar Hukum Agraria, Graha IImu, Yogyakarta, 2011, halaman 61 a. Mengatur dan menyelenggarakan peruntukan, penggunaan, persediaan, dan pemeliharaan bumi, air, dan ruang angkasa tersebut;

b. Menentukan dan mengatur hubungan-hubungan hukum antara orang-orang dengan bumi, air, dan ruang angkasa;

c. Menentukan dan mengatur hubungan-hubungan hukum antara orang-orang dan perbuatanperbuatan hukum yang mengenai bumi, air, dan ruang angkasa.

Wewenang yang bersumber pada hak menguasai dari Negara tersebut digunakan untuk tujuan mencapai sebesar-besar kemakmuran rakyat.

Atas dasar hak menguasai dari Negara tersebut, ditentukan adanya macam-macam hak atas permukaan bumi, yang disebut tanah, yang dapat diberikan kepada dan dipunyai oleh orangorang, baik sendiri maupun bersama-sama dengan orang lain serta badan-badan hukum. Hal itu yang disebutkan dalam Pasal 4 ayat 1 Undang-Undang Pokok Agraria.

Hak-hak atas tanah yang dimaksudkan dalam Pasal 4 Undang-Undang Pokok Agraria diatas ditentukan macamnya dalam Pasal 16 ayat 1 Undang-Undang Pokok Agraria, yaitu:
a. Hak milik;
b. Hak guna usaha;
c. Hak guna bangunan; 
d. Hak pakai;

e. Hak sewa;

f. Hak membuka tanah;

g. Hak memungut hasil hutan;

h. Hak-hak lain yang tidak termasuk dalam hak-hak tersebut di atas yang akan ditetapkan dengan Undang-Undang serta hak-hak yang sifatnya sementara sebagai yang disebutkan dalam Pasal 53.

Hak-hak atas tanah yang sifatnya sementara tersebut diatur dalam Pasal 53 UndangUndang Pokok Agraria yaitu hak gadai, hak usaha bagi hasil, hak menumpang, dan hak sewa tanah pertanian. Hak-hak atas tanah tersebut diatur untuk membatasi sifat-sifatnya yang bertentangan dengan Undang-Undang Pokok Agraria dan hak-hak tersebut diusahakan hapusnya di dalam waktu yang singkat.

\section{b. Subyek Hak Atas Tanah}

Ketentuan yang mengatur mengenai hak atas tanah, termasuk di dalamnya siapa saja yang dapat memiliki hak atas tanah tertentu terdapat dalam Undang-Undang Pokok Agraria, yaitu UndangUndang Nomor 5 Tahun 1960 tentang Peraturan Dasar Pokok-Pokok Agraria serta Peraturan Pemerintah Nomor 40 Tahun 1996 tentang Hak Guna Usaha, Hak Guna Bangunan dan Hak Pakai Atas Tanah.
Untuk pengaturan mengenai Hak Milik, diatur dalam Pasal 20 sampai dengan Pasal 27 UndangUndang Nomor 5 Tahun 1960. Hak Milik adalah hak yang turun temurun, terkuat, dan terpenuh yang dapat dipunyai orang atas tanah dengan mengingat fungsi sosial tanah. Hal tersebut dijelaskan oleh Pasal 20 Undang-Undang Pokok Agraria.

Subyek dari hak milik diatur dalam Pasal 21 Undang-Undang Nomor 5 Tahun 1960, yaitu hanya Warga Negara Indonesia dapat mempunyai hak milik. Sedangkan untuk suatu badan hukum pada dasarnya tidak diperkenankan memiliki tanah dengan status hak milik. Namun, dalam Pasal 21 ayat 2 Undang-Undang Pokok Agraria disebutkan bahwa oleh Pemerintah ditetapkan badan-badan hukum yang dapat mempunyai hak milik dan syarat-syaratnya.

Selain Warga Negara Indonesia dan badan hukum yang telah dijelaskan diatas, untuk orang asing apabila kita melihat Pasal 21 ayat 1 UndangUndang Pokok Agraria, tidak diperbolehkan untuk memiliki hak milik, karena hanya Warga Negara Indonesia yang dapat mempunyai hak milik. Namun, ada beberapa hal yang dapat menyebabkan orang asing tersebut dapat memperoleh tanah dengan status hak milik. Ketentuan tersebut terdapat dalam Pasal 21 ayat 3 Undang-Undang Nomor 5 Tahun 1960, yaitu orang asing yang sesudah berlakunya Undang-Undang Pokok Agraria memperoleh hak milik karena 
pewarisan tanpa wasiat atau percampuran harta karena perkawinan, demikian pula Warga Negara Indonesia yang mempunyai hak milik dan setelah berlakunya Undang-Undang Pokok Agraria kehilangan kewarganegaraannya wajib melepaskan hak itu dalam jangka waktu satu tahun sejak diperolehnya hak tersebut atau hilangnya kewarganegaraan itu. Jika sesudah jangka waktu tersebut lampau hak milik itu tidak dilepaskan, maka hak tersebut hapus karena hukum dan tanahnya jatuh kepada negara, dengan ketentuan bahwa hak-hak pihak lain yang membebaninya tetap berlangsung.

Setelah kita mengetahui siapa saja yang dapat memiliki hak milik, untuk seseorang maupun badan usaha yang ingin mengusahakan tanah yang langsung dikuasai oleh Negara dapat memiliki hak atas tanah dengan Hak Guna Usaha. Sesuai dengan penjelasan yang diberikan pada Pasal 28 Undang-Undang Pokok Agraria, Hak Guna Usaha adalah hak untuk mengusahakan tanah yang dikuasai langsung oleh Negara dalam jangka waktu tertentu guna perusahaan pertanian, perikanan, atau peternakan. Pemberian Hak Guna Usaha sesuai dengan Peraturan Pemerintah Nomor 40 Tahun 1996 Pasal 2, dapat diberikan kepada Warga Negara Indonesia dan badan hukum yang didirikan menurut hukum Indonesia dan berkedudukan di Indonesia.
Hak Guna Bangunan dapat kita temukan pengertiannya dalam Pasal 35 Undang-Undang Pokok Agraria, yaitu hak untuk mendirikan dan mempunyai bangunan-bangunan atas tanah yang bukan miliknya sendiri dengan jangka waktu tertentu. Siapa saja yang dapat memiliki hak atas tanah dengan status Hak Guna Bangunan dijelaskan dalam Pasal 19 Peraturan Pemerintah Nomor 40 Tahun 1996 diantaranya adalah Warga Negara Indonesia dan badan hukum yang didirikan menurut hukum Indonesia dan berkedudukan di Indonesia.

Selain Hak Milik, Hak Guna Usaha, dan Hak Guna Bangunan yang telah dijelaskan diatas, ada juga Hak Pakai, yang mana pengertiannya dijelaskan dalam Pasal 41 Undang-Undang Pokok Agraria, yaitu hak untuk menggunakan dan atau memungut hasil dari tanah yang dikuasai langsung oleh Negara atau tanah milik orang lain, yang memberi wewenang atau kewajiban yang ditentukan dalam keputusan pemberiannya oleh pejabat yang berwenang memberikannya atau dalam perjanjian dengan pemilik tanahnya, yang bukan perjanjian sewa-menyewa atau perjanjian pengolahan tanah, segala sesuatu asal tidak bertentangan dengan Undang-Undang Pokok Agraria.

Hak Pakai dapat diberikan selama jangka waktu tertentu atau selama tanahnya dipergunakan untuk keperluan tertentu, dan dapat dengan cuma- 
cuma, dengan pembayaran atau pemberian jasa berupa apapun. Serta, pemberian Hak Pakai tidak boleh disertai syarat-syarat yang mengandung unsur-unsur pemerasan. Hal ini dijelaskan dalam Pasal 41 ayat 2 dan ayat 3 Undang-Undang Pokok Agraria.

Mengenai pihak-pihak yang dapat memiliki tanah dengan status tanah Hak Pakai disebutkan dalam Pasal 39 Peraturan Pemerintah Nomor 40 Tahun 1996 antara lain:

a. Warga Negara Indonesia;

b. Badan hukum yang didirikan menurut hukum Indonesia dan berkedudukan di Indonesia;

c. Departemen, Lembaga Pemerintah Non Departemen, dan Pemerintah Daerah;

d. Badan-badan keagamaan dan sosial;

e. Orang asing yang berkedudukan di Indonesia;

f. Badan hukum asing yang mempunyai perwakilan di Indonesia;

g. Perwakilan negara asing dan perwakilan badan Internasional.

Untuk Orang asing yang dianggap berkedudukan di Indonesia sesuai penjelasan yang terdapat dalam Peraturan Pemerintah Nomor 40 Tahun 1996 adalah orang asing yang kehadirannya di Indonesia memberikan manfaat bagi pembangunan nasional.

\section{B. HASIL DAN PEMBAHASAN}

\section{Pengaturan kepemilikan hak atas tanah bagi orang asing di Indonesia}

Di Indonesia terkena imbas positif dalam era globalisasi, karena para investor asing yang ingin menanamkan investasinya di Indonesia semakin bertambah banyak. Namun, tidak semua orang asing yang mempunyai uang dapat memiliki hak atas tanah di Indonesia, sebab ada ketentuan yang membatasi pemilikan tanah dan bangunan bagi orang asing dan badan hukum asing dalam Undang-Undang Nomor 5 Tahun 1960 tentang Peraturan Dasar Pokok-Pokok Agraria (UUPA) dan berbagai peraturan pelaksananya. ${ }^{9}$

Pengertian orang asing di sini dapat dilihat dari Pasal 1 Undang-Undang Nomor 24 Tahun 2013 tentang perubahan atas Undang-Undang Nomor 23 Tahun 2006 tentang administrasi kependudukan, bahwa orang asing adalah orang bukan Warga Negara Indonesia. Begitu pula pengertian orang asing yang terdapat dalam Undang-Undang Nomor 6 Tahun 2011 tentang keimigrasian, orang asing adalah orang yang bukan Warga Negara Indonesia.

Adrian Sutadi mengatakan bahwa berkedudukan di Indonesia adalah orang asing yang melaksanakan kegiatan ekonomi di Indonesia

${ }^{9}$ Listyowati Sumanto, Pembatasan Pemilikan Hak Atas Tanah Oleh Orang Asing dan Badan Hukum Asing (Studi Perbandingan Indonesia-Turki), Jurnal Hukum Prioris, Vol.3 No.3, Tahun 2013 
dan pada waktu melakukan kegiatannya di Indonesia yang dilakukan secara berkala atau sewaktu-waktu, ia membutuhkan untuk mempunyai rumah tempat tinggal atau hunian di Indonesia. ${ }^{10}$ Arti kata orang asing yang berkedudukan di Indonesia yakni orang asing yang memiliki izin tinggal di Indonesia. Selain itu, izin tinggal bagi orang asing ini diperlukan bagi orang asing yang ingin memiliki rumah tempat tinggal atau hunian berupa rumah tunggal atau satuan rumah susun. Hal ini diatur dalam Peraturan Menteri Agraria dan Tata Ruang atau Kepala Badan Pertanahan Nasional Nomor 13 Tahun 2016 tentang Tata Cara Pemberian, pelepasan, atau pengalihan hak atas pemilikan rumah tempat tinggal atau hunian oleh orang asing yang berkedudukan di Indonesia. Izin tinggal ini dibagi menjadi lima izin tinggal, yakni izin tinggal diplomatik, izin tinggal dinas, izin tinggal kujungan, izin tinggal terbatas, dan izin tinggal tetap.

Selain itu, kita dapat juga melihat di dalam Undang-Undang Darurat Nomor 9 Tahun 1955 tentang Kependudukan Orang Asing yang dibolehkan tinggal di Indonesia dibagi menjadi dua golongan, yaitu yang pertama, mereka yang memperoleh izin masuk (admission) dengan memperoleh hak untuk tinggal di Indonesia untuk jangka waktu tertentu, yang kedua, mereka yang dibolehkan untuk tinggal di Indonesia dan

10 Adrian Sutadi, Tinjauan Hukum Pertanahan, Pradnya Paramita, Jakarta, 2009, halaman 268 dipandang sebagai penduduk dengan dasar menetap atau gevestegd. ${ }^{11}$

Sedangkan bila kita lihat dalam ketentuan yang terdapat dalam Undang-Undang Pokok Agraria Pasal 42, disebutkan bahwa selain Warga Negara Indonesia, badan hukum yang didirikan menurut hukum Indonesia dan berkedudukan di Indonesia, badan hukum asing yang mempunyai perwakilan di Indonesia, juga terdapat orang asing yang berkedudukan di Indonesia yang dapat mempunyai hak atas tanah dengan hak pakai di Indonesia. Berbeda dengan Peraturan Pemerintah Nomor 103 Tahun 2015 tentang Pemilikan Rumah Tempat Tinggal atau Hunian Oleh Orang Asing yang Berkedudukan di Indonesia memberikan pengertian yang lebih luas, yaitu orang yang bukan Warga Negara Indonesia yang keberadaannya memberikan manfaat, melakukan usaha, bekerja, atau berinvestasi di Indonesia. Pengertian orang asing yang terdapat dalam Peraturan Pemerintah Nomor 103 Tahun 2015 tersebut memberikan pesan bahwa orang asing yang berkedudukan di Indonesia harus memiliki pekerjaan, serta dapat memberikan manfaat di Indonesia, hal ini tentunya supaya dapat mencegah orang asing tersebut justru menjadi beban untuk Indonesia kalau ia tidak memiliki penghasilan selama berada di Indonesia.

\footnotetext{
11 Maria S.W.Sumardjono (Selanjutnya disebut Maria S.W.Sumardjono-3), Kebijakan Pertanahan Antara Regulasi dan Implementasi, Kompas, Jakarta, 2001, halaman 134
} 
Pengertian berkedudukan di Indonesia tidak harus diartikan sama dengan tempat kediaman atau domisili, akan tetapi orang asing tersebut melaksanakan kegiatan ekonomi di Indonesia dan pada waktu kegiatan tersebut dilakukan secara berkala atau sewaktu-waktu. Di bidang ekonomi, orang dapat memiliki kepentingan yang harus dipelihara tanpa harus menunggunya secara fisik apalagi untuk waktu yang cukup panjang dan secara terus-menerus. Dengan kemajuan di bidang teknologi transportasi dan komunikasi memungkinkan orang memelihara kepentingan yang dimilikinya di negara lain tanpa harus menunggui sendiri. Kadang kala, mereka cukup hadir secara berkala. Dalam keadaan seperti itu, yang mereka perlukan adalah fasilitas tempat tinggal atau hunian bila secara berkala tetapi teratur harus datang untuk mengurus atau memelihara kepentingannya. ${ }^{12}$

Pengertian dari izin tinggal itu sendiri menurut menurut Undang-Undang Nomor 6 Tahun 2011 tentang Keimigrasian, adalah izin yang diberikan kepada orang asing oleh pejabat imigrasi atau pejabat dinas luar negeri untuk berada di wilayah Indonesia. Serta, dalam Peraturan Pemerintah Nomor 31 Tahun 2013 tentang pelaksanaan Undang-Undang Nomor 6 Tahun 2011 tentang Keimigrasian, mengatur bahwa setiap orang asing yang berada di wilayah Indonesia wajib

12 Urip Santoso, Hukum Perumahan, Kencana, Surabaya, 2014, halaman 355 memiliki izin tinggal. Izin tinggal ini diberikan kepada orang asing sesuai dengan visa yang dimilikinya.

Orang asing yang berkedudukan di Indonesia, sudah memiliki izin tinggal di Indonesia, sesuai dengan ketentuan Peraturan Pemerintah Nomor 103 Tahun 2015, yakni juga memiliki pekerjaan di Indonesia, dalam hal ini bekerja maupun investasi, berdasarkan hasil wawancara yang peneliti lakukan di Kantor imigrasi Semarang dengan bapak Irfan ${ }^{13}$, beliau menjabat sebagai kepala bagian umum, bahwa sebelum orang asing tersebut masuk ke Indonesia, untuk bekerja di Indonesia, haruslah melalui persyaratan yang diajukan oleh Dinas Tenaga kerja dan Transmigrasi.

Awal dari seorang tenaga kerja asing yang akan masuk ke wilayah Indonesia, dikarenakan adanya sebuah perusahaan yang memerlukan tenaga ahli, sehingga ia harus mendatangkan dari luar negeri. Berdasarkan hasil wawancara yang peneliti lakukan di Dinas Tenaga Kerja dan Transmigrasi dengan ibu Arum Dwi Rahayu ${ }^{14}$, beliau di bagian perijinan tenaga kerja asing Dinas Tenaga Kerja dan Transmigrasi kota Semarang, Perusahaan yang akan mendatangkan tenaga kerja asing ke Indonesia disebut "pengguna", atau

\footnotetext{
13 Wawancara dengan Irfan, Kepala Bagian Umum Kantor Imigrasi semarang

14 Wawancara dengan Arum Dwi Rahayu, bagian Perijinan tenaga kerja asing, Dinas Tenaga Kerja dan Transmigrasi Kota Semarang
} 
pemberi kerja tenaga kerja asing. Untuk izin yang pertama kali, dilakukan untuk memasukkan tenaga kerja asing di Indonesia melalui Kementrian Ketenagakerjaan Republik Indonesia. Setelah disetujui, maka Kementrian Ketenagakerjaan menerbitkan Rencana Penggunaan Tenaga Kerja Asing, yang mana Rencana Penggunaan Tenaga Kerja Asing ini melekat pada "pengguna" tenaga kerja asing tersebut.

Rencana Penggunaan Tenaga Kerja Asing ini berlaku paling lama lima tahun dan dapat diperpanjang dengan mempertimbangkan kondisi pasar kerja dalam negeri. Selanjutnya setelah mendapatkan Rencana Penggunaan Tenaga Kerja Asing tersebut, Kementrian Ketenagakerjaan Republik Indonesia memberikan Izin Mempekerjakan Tenaga Kerja Asing kepada pemberi kerja tenaga kerja asing tersebut.

Ibu Arum Dwi Rahayu ${ }^{15}$ juga mengemukakan bahwa Izin Mempekerjakan Tenaga Kerja Asing ini melekat pada tenaga kerja asing tersebut. Jangka waktu yang diberikan untuk Izin Mempekerjakan Tenaga Kerja Asing berdasarkan Menurut Peraturan Menteri Ketenagakerjaan Nomor 16 Tahun 2015 tentang Tata cara penggunaan tenaga kerja asing, yang telah dirubah dengan Peraturan Menteri Ketenagakerjaan Nomor 35 Tahun 2015 tentang Perubahan atas peraturan menteri ketenagakerjaan

15 Wawancara dengan Arum Dwi Rahayu, bagian Perijinan tenaga kerja asing, Dinas Tenaga Kerja dan Transmigrasi Kota Semarang
Nomor 16 Tahun 2015 tentang Tata cara penggunaan tenaga kerja asing, dalam Pasal 39 ayat (2) ialah satu tahun, dan dapat diperpanjang dengan keputusan Menteri. Sedangkan di dalam Pasal 39 ayat (5), Izin Mempekerjakan Tenaga Kerja Asing, yang mana tenaga kerja asing tersebut sebagai anggota direksi, sebagai anggota dewan komisaris, sebagai anggota pembina, sebagai anggota pengurus, sebagai anggota pengawas, maka izin tersebut dapat diberikan dua tahun, serta dapat diperpanjang.

Perpanjangan Izin Mempekerjakan Tenaga Kerja Asing ini berdasarkan Peraturan Menteri Ketenagakerjaan Nomor 16 Tahun 2015 tentang Tata cara penggunaan tenaga kerja asing, yang telah dirubah dengan Peraturan Menteri Ketenagakerjaan Nomor 35 Tahun 2015 tentang Perubahan atas peraturan menteri ketenagakerjaan Nomor 16 Tahun 2015 tentang Tata cara penggunaan tenaga kerja asing, dalam Pasal 43, dapat diajukan paling lambat 30 hari kerja sebelum jangka waktu berlakunya Izin Mempekerjakan Tenaga Kerja Asing berakhir, serta dalam Pasal 42, perpanjangan Izin Mempekerjakan Tenaga Kerja Asing diterbitkan oleh:

a. Direktur untuk tenaga kerja asing yang lokasi kerjanya lebih dari satu wilayah propinsi.

b. Kepala Dinas Propinsi, untuk tenaga kerja asing yang lokasi kerjanya lintas kabupaten atau kota dalam satu propinsi. 
c. Kepala Dinas Kabupaten atau kota, untuk tenaga kerja asing yang lokasi kerjanya dalam satu wilayah kabupaten atau kota.

Setelah orang asing tersebut memenuhi syarat untuk bekerja ataupun berinvestasi di Indonesia, dalam hal ia memerlukan tempat tinggal atau hunian, berdasarkan Pasal 2 Peraturan Pemerintah Nomor 103 Tahun 2015 tentang Pemilikan rumah tempat tinggal atau hunian oleh orang asing yang berkedudukan di Indonesia, orang asing pemegang izin tinggal di Indonesia dapat memiliki rumah atau tempat tinggal atau hunian dengan Hak Pakai. Berdasarkan hasil wawancara yang dilakukan oleh peneliti kepada Bapak Suroso ${ }^{16}$, bagian Penetapan Hak Tanah, Kantor Pertanahan Semarang, bahwa orang asing yang dapat memiliki rumah tinggal, hunian di Indonesia yaitu orang asing yang berkedudukan di Indonesia. Berkedudukan disini menurut beliau, memiliki arti orang asing yang mempunyai izin tinggal di Indonesia, sehingga keberadaannya di Indonesia sifatnya tidak untuk sementara.

Selain itu, ketentuan yang terdapat dalam Pasal 4 nya mengatakan bahwa rumah tempat tinggal atau hunian yang dapat dimiliki oleh orang asing yaitu:

a. Rumah tinggal di atas tanah:

1. Hak pakai; atau

${ }^{16}$ Wawancara dengan Suroso, Bagian Penetapan hak tanah, Kantor Pertanahan Semarang
2. Hak pakai di atas Hak Milik yang dikuasai berdasarkan perjanjian pemberian Hak Pakai di atas Hak Milik dengan akta Pejabat Pembuat Akta Tanah.

b. Sarusun yang dibangun di atas bidang tanah Hak Pakai.

Mengenai jangka waktu orang asing dapat memiliki rumah tunggal ini diatur dalam Pasal 6 Peraturan Pemerintah Nomor 103 Tahun 2015 tentang Pemilikan rumah tempat tinggal atau hunian oleh orang asing yang berkedudukan di Indonesia, yaitu untuk rumah tunggal yang diberikan di atas tanah Hak Pakai diberikan jangka waktu 30 tahun, kemudian Hak Pakai tersebut dapat diperpanjang untuk jangka waktu 20 tahun, serta setelah perpanjangan tersebut berakhir, Hak Pakai dapat diperbaharui untuk jangka waktu 30 tahun. Ketentuan mengenai jangka waktu tersebut sama dengan rumah tunggal di atas tanah Hak Pakai di atas Hak Milik yang dikuasai berdasarkan perjanjian, sebagaimana yang diatur dalam Pasal 7 Peraturan Pemerintah Nomor 103 Tahun 2015 tentang Pemilikan rumah tempat tinggal atau hunian oleh orang asing yang berkedudukan di Indonesia.

\section{SIMPULAN DAN SARAN}

Berdasarkan uraian di atas, maka dapat disimpulkan sebagai berikut:

Pengaturan kepemilikan hak atas tanah bagi Warga Negara Asing di Indonesia aturan yang mengatur 
sudah sangat jelas. Mulai dari Undang-Undang Dasar Negara Republik Indonesia, dalam Pasal 33 ayat (3), kemudian Undang-Undang Nomor 5 Tahun 1960 tentang Undang-Undang Pokok Agraria, serta dalam Peraturan Pelaksananya, yaitu Peraturan Pemerintah Nomor 103 Tahun 2015 tentang pemilikan rumah tempat tinggal atau hunian oleh orang asing yang berkedudukan di Indonesia pun sudah diatur mengenai pengaturan kepemilikan hak atas tanah bagi Warga Negara Asing di Indonesia. Selain itu, aturan-aturan tersebut juga sangat berkaitan dengan aturan yang terdapat dalam keimigrasian, dan aturan yang terdapat dalam Dinas Ketenagakerjaan. Ada aturan-aturan lainnya yang terkait, seperti aturan yang mengatur mengenai perumahan, serta aturan mengenai Badan Hukum, khususnya Perseroan Terbatas.

Berdasarkan kesimpulan tersebut, maka disarankan:

Perlu dilakukannya evaluasi terhadap aturan yang saat ini sudah berlaku, apakah sudah sesuai dengan kebutuhan bangsa Indonesia, apakah sudah dijalankan dengan tujuan untuk sebesarbesar rakyat Indonesia. Aturan yang terdapat dalam Peraturan Pemerintah Nomor 103 Tahun 2015, disana dikatakan bahwa kepemilikan Hak Pakai oleh orang asing yang berkedudukan di Indonesia diberikan sampai dengan jangka waktu 30 tahun lamanya, itupun dapat diperpanjang 20 tahun, serta dapat diperbaharui selama 30 tahun lamanya. Hal ini perlu dikaji ulang, apakah memang diperlukan jangka waktu yang sedemikian panjangnya untuk orang asing dapat memiliki hak atas tanah di Indonesia.

\section{DAFTAR PUSTAKA}

\section{A. Buku}

Hanitijo, Ronny, Soemitro, 1992, Metodologi Penelitian Dan J urimetri, Jakarta : Ghalia

Harsono, Boedi, 2008, Hukum Agraria Indonesia, Sejarah Pembentukan Undang-Undang Pokok Agraria Isi Dan Pelaksanaannya, Jakarta: Djambatan

Ismaya, Samun, 2011, Pengantar Hukum Agraria, Yogyakarta : Graha IImu

Parlindungan,A,P, 1990, Komentar Atas UndangUndang Pokok Agraria, Bandung: Alumni

Santoso, Urip, 2012, Hukum Agraria Kajian Komprehensif, Jakarta : Kencana

------, Hukum Perumahan, 2014, Surabaya: Kencana

Soekanto, Soerjono, 1988, Pendekatan Sosiologi Terhadap Hukum, Jakarta : Bina Aksara

Sumardjono, S.W, Maria , 2001, Kebijakan Pertanahan Antara Regulasi dan Implementasi, Jakarta: Kompas

Supramono, Gatot, 2012, Hukum Orang Asing di Indonesia, Banjarmasin: Sinar Grafika

Sutadi, Adrian, 2009, Tinjauan Hukum Pertanahan, Jakarta: Pradnya Paramita 


\section{B. Undang-Undang}

Undang-Undang Nomor 5 Tahun 1960 tentang Peraturan Dasar Pokok-Pokok Agraria

Undang-Undang Nomor 24 Tahun 2013 tentang perubahan atas Undang-Undang Nomor 23 Tahun 2006 tentang administrasi kependudukan

Undang-Undang Nomor 6 Tahun 2011 tentang keimigrasian

Undang-Undang Darurat Nomor 9 Tahun 1955 tentang Kependudukan Orang Asing

\section{Peraturan Pemerintah}

Peraturan Pemerintah Nomor 40 Tahun 1996 tentang Hak Guna Usaha, Hak Guna Bangunan dan Hak Pakai Atas Tanah

Peraturan Pemerintah Nomor 103 Tahun 2015 tentang Pemilikan Rumah Tempat Tinggal atau Hunian Oleh Orang Asing yang Berkedudukan di Indonesia

Peraturan Pemerintah Nomor 31 Tahun 2013 tentang pelaksanaan Undang-Undang Nomor 6 Tahun 2011 tentang Keimigrasian

\section{Peraturan Menteri}

Peraturan Menteri Agraria dan Tata Ruang atau Kepala Badan Pertanahan Nasional Nomor 13 Tahun 2016 tentang Tata Cara Pemberian, pelepasan, atau pengalihan hak atas pemilikan rumah tempat tinggal atau hunian oleh orang asing yang berkedudukan di Indonesia

Peraturan Menteri Ketenagakerjaan Nomor 35 Tahun 2015 tentang Perubahan atas peraturan menteri ketenagakerjaan Nomor 16 Tahun 2015 tentang Tata cara penggunaan tenaga kerja asing

\section{E. J urnal}

Sumanto, Listyowati, 2013, Pembatasan Pemilikan Hak Atas Tanah Oleh Orang Asing dan Badan Hukum Asing (Studi Perbandingan Indonesia-Turki), Jurnal Hukum Prioris, Vol.3 No.3 